\title{
Article \\ Transcription of Listeria monocytogenes Key Virulence Genes on Tomato, Cucumber and Carrot
}

\author{
Spiros Paramithiotis *(D), Christina Kotsakou (D) and Eleftherios H. Drosinos
}

check for updates

Citation: Paramithiotis, S.; Kotsakou, C.; Drosinos, E.H. Transcription of Listeria monocytogenes Key Virulence Genes on Tomato, Cucumber and Carrot. Appl. Sci. 2021, 11, 5983. https: / / doi.org/10.3390/ app11135983

Academic Editors: Nikolaos

D. Andritsos, Emmanouil

N. Velonakis and Galatios

D. Moschonas

Received: 28 April 2021

Accepted: 25 June 2021

Published: 27 June 2021

Publisher's Note: MDPI stays neutral with regard to jurisdictional claims in published maps and institutional affiliations.

Copyright: (c) 2021 by the authors. Licensee MDPI, Basel, Switzerland. This article is an open access article distributed under the terms and conditions of the Creative Commons Attribution (CC BY) license (https:// creativecommons.org/licenses/by/ $4.0 /)$.
Laboratory of Food Quality Control and Hygiene, Department of Food Science and Human Nutrition, Agricultural University of Athens, Iera Odos 75, GR-11855 Athens, Greece; xristinakots91@hotmail.com (C.K.); ehd@aua.gr (E.H.D.)

* Correspondence: sdp@aua.gr

\begin{abstract}
The aim of the present study was to assess the transcription of Listeria monocytogenes key virulence genes, namely sigB, prf $A, h l y, p l c A, p l c B, i n l A, i n l B$, inlC and inlJ during subsistence on the surface of tomato, cucumber and carrot stored at 4,10 and $30{ }^{\circ} \mathrm{C}$ for $0,0.5,6$ and $24 \mathrm{~h}$. Gene relative transcription was assessed through reverse transcription-quantitative polymerase chain reaction (RT-qPCR). The results obtained, indicated that the relative transcription of $p l c A, p l c B$ and inlB was more affected during subsistence on cucumber surface whereas the relative transcription of $\operatorname{sig} B$, $\operatorname{prf} A, h l y$, inlA and inlC was more affected on tomato surface. Subsistence of the pathogen on carrot surface had only marginal effect on the relative transcription of the virulence genes assessed in the present study. In the majority of the cases, the aforementioned effects were dependent on the storage temperature employed.
\end{abstract}

Keywords: Listeria monocytogenes; virulence associated genes; liquid medium; tomato; cucumber; carrot

\section{Introduction}

Listeria monocytogenes is the etiological agent of foodborne listeriosis, the latest reports on which mention in the United States of America a total of 32 illnesses, 31 hospitalizations and 3 deaths (2017 annual report available at https: / / www.cdc.gov / fdoss / annual-reports / index.html (accessed on 20 May 2021)) and in the EU a total of 2621 confirmed cases, 1339 hospitalizations and 300 deaths (2019 annual report available at https: / / www.efsa.europa. eu/en/efsajournal/pub/6406 (accessed on 20 May 2021)). The virulence potential of this foodborne pathogen relies on the ability to cross the intestinal epithelial cells, escape from host defensive responses and disseminate through lymph and blood [1]. This infection requires the coordinated expression of a series of genes, including $h l y, p l c A, p l c B$, inl $A$, inlB, inlC and inlJ. hly encodes for listeriolysin O (LLO) a cholesterol-dependent poreforming toxin that, among several functions, it facilitates internalization into host cells and escape from host phagosomes through a pore-dependent mechanism [2]. plcA and plcB encode for phosphatidylinositol phospholipase $C$ and phosphatidylcholine phospholipase $\mathrm{C}$, respectively. The cooperation of both phospholipases with LLO is required for escape of the pathogen from the phagocytic vacuole [3]. Internalins InlA, InlB, InlC and InlJ are necessary for effective invasion. InlA and InlB bind to E-cadherin and the hepatocyte growth factor receptor, respectively, which are receptors of the eukaryotic cell membrane. In both cases, bacterial endocytosis is induced [1]. InlC enables cell-to-cell spread of the pathogen by facilitating the formation of protrusions in the cell membrane of apical junctions [4]. InlJ is also important, as suggested by the significantly attenuated virulence capacity of the deletion mutant [5]; however, the mode of action is yet to be identified. The transcriptional control of these genes has been assigned to the alternative sigma factor $B\left(\sigma^{B}\right)$ and the positive regulatory factor A (PrfA). The alternative sigma factor $\mathrm{B}$ is encoded by $\operatorname{sig} B$ and has a key role in L. monocytogenes survival in nature and in 
the gastrointestinal tract. It controls the transcription of more than 200 genes, affecting substantially L. monocytogenes responses to environmental stimuli and virulence [6]. The latter is achieved through the transcriptional control of several virulence-associated genes, including $\operatorname{prfA}$. The latter encodes PrfA that directly regulates transcription of twelve key virulence genes and indirectly a total of 145 genes. Thus, it possesses a key role in directing cellular homeostasis and fine-tuning the virulence machinery of L. monocytogenes [7].

The effect that several factors associated with food processing may have on the transcription of genes related to L. monocytogenes virulence has been studied to some extent. However, only a few studies address the combined effect that the food matrix, storage time and temperature as well as strain diversity may have. More accurately, Olesen et al. [8], Bae et al. [9], Rantsiou et al. [10,11] and Mataragas et al. [12] studied the transcription of key virulence genes of the pathogen on meat products, Duodu et al. [13] and Pilevar et al. [14] on fish products, Rantsiou et al. [11] and Alessandria et al. [15] on dairy products and Hadjilouka et al. [16] and Kang et al. [17] on fruits and vegetables. The significance of these studies is highlighted by the fact that prior exposure to environmental stimuli affects invasiveness [18-32] and that upregulation of virulence associated genes observed during such exposure is correlated with increased invasion efficiency [13,21].

Tomatoes, cucumbers and carrots are very important vegetables, both in terms of nutritional value (https:/ fdc.nal.usda.gov/ (accessed on 20 May 2021)) and commercial importance (http:/ / www.fao.org/faostat/en/\#data/QV (accessed on 20 May 2021)). Many authors have studied the prevalence of L. monocytogenes in these commodities. In cucumbers, it has been reported below 7\% [33-35]; however, Arumugaswamy et al. [36], Poonniah et al. [37] and Ajayeoba et al. [38] reported detection of the pathogen in the $80 \%, 43.8 \%$ and $23.4 \%$, respectively, of the samples assessed. A rather high prevalence has been reported for tomatoes. More accurately, Vahidy et al. [34] reported 13.3\%, Pooniah et al. [37] 21.9\% and Ajayeoba et al. [38] 19.67\%. However, many studies have reported its absence [33,39-41]. Similar is the case of carrots, Ponniah et al. [37] reported a prevalence of $24.2 \%$ while Ajayeoba et al. [38] of $9.02 \%$. On the contrary, Heisick et al. [33], Vahidy et al. [34] and Odumeru et al. [42] reported absence in the samples assessed.

Outbreaks linked to the consumption of tomatoes and cucumbers usually involve Salmonella serovars as etiological agents. On the other hand, illnesses related to carrot consumption have been mostly assigned to Norovirus, Shigella ssp. and botulism (data retrieved from outbreakdatabase.com (accessed on 20 May 2021)). However, based on the rather high prevalence values and their widespread and general applicability, their implication in L. monocytogenes outbreaks would also be reasonable, either through direct consumption or through cross-contamination. So far, only one recorded outbreak has been partially linked to tomato consumption. More accurately, Ho et al. [43] reported that the $L$. monocytogenes outbreak that took place in 1979 in Boston and involved 23 patients from eight hospitals, could be assigned to the consumption of celery, lettuce and tomatoes.

The aim of the present study was to provide information regarding the transcriptional response of L. monocytogenes during subsistence on the surface of tomato, cucumber and carrot, stored at 4,10 and $30^{\circ} \mathrm{C}$. More accurately, data regarding the relative transcription of $\operatorname{sig} B, p r f A, p l c A, p l c B, h l y$, inlA, inlB, inlC and inlJ could improve the accuracy of risk assessment studies and enable the development of commodity-specific control strategies.

\section{Materials and Methods}

\subsection{Bacterial Strain, Inoculum and Sample Preparation}

L. monocytogenes strain LQC 15257, serotype $4 b$, isolated from a strawberry sample [44] was used throughout this study. The strain was stored at $-20^{\circ} \mathrm{C}$ in Nutrient broth (Lab M, Lancashire, UK) supplemented with $50 \%$ glycerol. Before experimental use, the strain was grown twice in Brain Heart Infusion (BHI) broth (Lab M) at $37^{\circ} \mathrm{C}$ for $24 \mathrm{~h}$.

The inoculum was prepared as follows: overnight culture of the strain $(9 \log \mathrm{CFU} / \mathrm{mL})$ was centrifuged $\left(12,000 \times g ; 15 \mathrm{~min} ; 4^{\circ} \mathrm{C}\right)$, washed twice with sterile Ringer's solution (Lab 
$\mathrm{M})$, resuspended in the same diluent and used to inoculate BHI broth, cucumber, carrot and tomato samples.

Fresh carrots, cucumbers and tomatoes were purchased from local markets and were examined for L. monocytogenes occurrence according to EN ISO 11290-1: 2017. Once absence of the pathogen was verified, they were thoroughly washed with tap water and cut in slices. Carrot slices of 2.5-3.0 cm diameter and ca. $0.5 \mathrm{~cm}$ thickness, cucumber slices of $4.0-5.0 \mathrm{~cm}$ diameter and ca. $0.5 \mathrm{~cm}$ thickness and tomato slices of $6.0-7.0 \mathrm{~cm}$ diameter and ca. $1 \mathrm{~cm}$ thickness were used for the experiment. The slices were placed in sterile containers (volume ca. $500 \mathrm{~mL}$ ) according to the product type, placed at the intended incubation temperature (i.e., 4,10 and $30^{\circ} \mathrm{C}$ ) overnight for temperature equilibration and sprayed with $0.5 \mathrm{~mL}$ of pathogen culture previously adjusted to proper concentration. Similarly, BHI broth was also inoculated with $0.5 \mathrm{~mL}$ of the diluted pathogen after temperature equilibration. BHI broth, cucumber, carrot and tomato samples were inoculated with 7.00-7.50 log CFU/mL or $\log \mathrm{CFU} / \mathrm{g}$, respectively. The experiment was performed in triplicate.

\subsection{Sampling and Microbiological Analyses}

Sampling was performed immediately after inoculation (designated as time $0 \mathrm{~h}$ ) and after $0.5,6$ and $24 \mathrm{~h}$ of incubation at 4,10 and $30^{\circ} \mathrm{C}$. For microbiological analyses, $10 \mathrm{~g}$ of the vegetable sample was aseptically homogenized with $90 \mathrm{~mL}$ sterile Ringer's solution with the aid of a Stomacher apparatus (Seward, London, UK). In the case of BHI broth, $1 \mathrm{~mL}$ of substrate was aseptically homogenized with $9 \mathrm{~mL}$ of sterile Ringer's solution. In both cases, Ringer's solution was previously equilibrated at sample temperature. The homogenates were serially diluted in the same diluent, plated on Polymyxin Acriflavine Lithium chloride Ceftazidine Aesculin Mannitol (PALCAM) agar (Lab M) as well as BHI agar; incubation took place at $37^{\circ} \mathrm{C}$ for $48 \mathrm{~h}$. L. monocytogenes populations reported refer to enumeration on PALCAM agar.

\subsection{In Vitro and In Situ Gene Transcription Assay}

After sample homogenization, $10 \mathrm{~mL}$ of the homogenate was transferred in sterile Falcon ${ }^{\circledR}$ tubes and centrifuged $(12,000 \times g ; 1 \mathrm{~min}$; sample temperature). Then, the supernatant was discarded and the biomass was mixed with $200 \mu \mathrm{L}$ of RNAlater ${ }^{\circledR}$ solution (Ambion, Whaltham, MA, USA). RNA was extracted with the NucleoSpin ${ }^{\circledR}$ RNA Kit (Macherey-Nagel, Dueren, Germany); cDNA synthesis took place with the PrimeScript ${ }^{\mathrm{TM}}$ One Step RT-PCR Kit (Takara Bio, Shiga, Japan) using random hexamers. Two reverse transcription reactions (+RT) and one without the addition of reverse transcriptase (-RT) were performed for each sample, containing ca. $0.5 \mu \mathrm{g}$ RNA each. The primers and PCR conditions were according to Hadjilouka et al. [45]. Real-Time qPCR was performed using KAPA SYBR qPCR Kit Master Mix (2X) ABI Prism (KapaBiosystems, Boston, MA, USA). No template controls (NTC) were also included to detect reagent contamination. The Ct values of the genes under study were processed only if the difference between $+\mathrm{RT}$ and -RT was at least 10 cycles and no amplification was observed in NTC.

\subsection{Statistical Analysis}

The $\mathrm{Ct}$ values of reference and virulence-associated genes were processed according to Hadjilouka et al. [45] and the calculated fold change was converted to the respective $\log _{2}$ values for further processing. Based on the stability values calculated by NormFinder [46], IGS was used for normalization. The condition used as control is mentioned in each case. The relative transcription of a gene was considered as down- or up-regulated when the $\log _{2}$ value of the fold change $\left(\log _{2} \mathrm{FC}\right)$ was below -1 or above 1 , respectively, assessed through one-sample $t$-test $(p<0.05)$. The correlation between the $\log _{2} \mathrm{FC}$ values of the genes was assessed by the Pearson coefficient. One-way analysis of variance (ANOVA) was performed to assess the differences between the population of the pathogen at each sampling time. All calculations were performed in Statgraphics Centurion XVII. 


\section{Results}

In Table 1, the dynamics of the L. monocytogenes population during incubation of BHI broth, carrot, cucumber and tomato at 4,10 and $30^{\circ} \mathrm{C}$, are exhibited. Increase of the $L$. monocytogenes population was only observed during incubation of $\mathrm{BHI}$ broth at 10 and $30{ }^{\circ} \mathrm{C}$ as well as during incubation of cucumber at $30^{\circ} \mathrm{C}$.

Table 1. L. monocytogenes population dynamics $\left(\log \mathrm{CFU} \mathrm{mL} \mathrm{m}^{-1}\right.$ or $\left.\mathrm{g}^{-1}\right)$ in $\mathrm{BHI}$ broth, on cucumber, carrot and tomato during incubation at 4,10 and $30^{\circ} \mathrm{C}$.

\begin{tabular}{|c|c|c|c|c|c|}
\hline \multirow[b]{2}{*}{ Temperature $\left({ }^{\circ} \mathrm{C}\right)$} & \multirow[b]{2}{*}{ Time (h) } & \multicolumn{4}{|c|}{ Substrate } \\
\hline & & $\begin{array}{c}\text { BHI Broth } \\
\left(\log \text { CFU mL } \mathrm{mL}^{-1}\right)\end{array}$ & $\begin{array}{l}\text { Cucumber } \\
\left(\log \text { CFU g }{ }^{-1}\right)\end{array}$ & $\begin{array}{c}\text { Carrot } \\
\left(\log \text { CFU g }{ }^{-1}\right)\end{array}$ & $\begin{array}{c}\text { Tomato } \\
\left(\log \text { CFU } g^{-1}\right)\end{array}$ \\
\hline \multirow[t]{4}{*}{4} & 0 & $7.23(0.20)^{\mathrm{a}}$ & $7.15(0.22)^{a}$ & $7.23(0.25)^{b c}$ & $7.11(0.24)^{a}$ \\
\hline & 0.5 & $7.35(0.37)^{\mathrm{a}}$ & $7.31(0.31)^{\mathrm{a}}$ & $7.33(0.37)^{\mathrm{c}}$ & $7.17(0.47)^{\mathrm{a}}$ \\
\hline & 6.0 & $7.34(0.40)^{\mathrm{a}}$ & $7.26(0.33)^{\mathrm{a}}$ & $6.56(0.42)^{\mathrm{a}}$ & $7.23(0.52)^{\mathrm{a}}$ \\
\hline & 24.0 & $7.42(0.33)^{\mathrm{a}}$ & $6.79(0.20)^{\mathrm{a}}$ & $6.60(0.24)^{a b}$ & $6.94(0.59)^{a}$ \\
\hline \multirow[t]{4}{*}{10} & 0 & $7.20(0.10)^{\mathrm{a}}$ & $7.22(0.31)^{a}$ & $7.34(0.21)^{\mathrm{a}}$ & $7.13(0.19)^{\mathrm{a}}$ \\
\hline & 0.5 & $7.36(0.11)^{\mathrm{a}}$ & $7.09(0.38)^{\mathrm{a}}$ & $7.19(0.37)^{\mathrm{a}}$ & $7.36(0.14)^{\mathrm{a}}$ \\
\hline & 6.0 & $7.69(0.13)^{b}$ & $6.92(0.14)^{a}$ & $7.10(0.41)^{\mathrm{a}}$ & $7.36(0.51)^{a}$ \\
\hline & 24.0 & $8.12(0.22)^{c}$ & $6.99(0.15)^{\mathrm{a}}$ & $6.89(0.51)^{\mathrm{a}}$ & $7.21(0.38)^{a}$ \\
\hline \multirow[t]{4}{*}{30} & 0 & $7.20(0.13)^{\mathrm{a}}$ & $7.52(0.35)^{\mathrm{a}}$ & $7.38(0.27)^{a b}$ & $7.34(0.21)^{\mathrm{a}}$ \\
\hline & 0.5 & $7.65(0.10)^{b}$ & $7.77(0.12)^{a b}$ & $7.51(0.33)^{b}$ & $7.44(0.27)^{\mathrm{a}}$ \\
\hline & 6.0 & $8.19(0.27)^{\mathrm{c}}$ & $8.28(0.30)^{b}$ & $6.73(0.39)^{\mathrm{a}}$ & $7.20(0.37)^{\mathrm{a}}$ \\
\hline & 24.0 & $9.00(0.12)^{d}$ & $8.25(0.32)^{b}$ & $6.86(0.40)^{a b}$ & $7.20(0.40)^{\mathrm{a}}$ \\
\hline
\end{tabular}

Standard deviation is given in parenthesis. Within a column, for each temperature, different superscript letters denote statistically significant differences $(p<0.05)$.

In Figures 1 and 2, the effect of substrate and temperature on the relative transcription of $\operatorname{sig} B, p r f A, p l c A, p l c B, h l y$, inlA, inlB, inlC and inlJ is exhibited. These results are summarized in Table 2.

In general, the relative transcription of all genes under study but $h l y$, seemed to be unaffected by the substrate, since, in the $66.9 \%$ of the cases, the $\log _{2}(\mathrm{FC})$ value ranged between -1 and 1 (Table 2), which was not considered as regulation. However, there were notable exceptions. More accurately, transcription of $\operatorname{sig} B$ and $p l c B$ were affected on tomato and cucumber, respectively. $\operatorname{sig} B$ was downregulated on tomato at all temperatures assessed while downregulation of $p l c B$ was noted at $4{ }^{\circ} \mathrm{C}$ and a mixed response, i.e., up- and downregulation at different sampling times at 10 and $30^{\circ} \mathrm{C}$ (Figure 1). Transcription of $p r f A$ was affected on cucumber and tomato. More accurately, in the former case, downregulation was evident at 4 and $10{ }^{\circ} \mathrm{C}$, while in the latter case a mixed response at $4{ }^{\circ} \mathrm{C}$ and upregulation at $30^{\circ} \mathrm{C}$ were observed. In addition, transcription of inlA and inlC was affected on tomato. In the first case, upregulation was observed at 10 and $30{ }^{\circ} \mathrm{C}$ and a mixed response at $4{ }^{\circ} \mathrm{C}$ (Figure 1). On the contrary, upregulation of $i n l C$ was observed at $30{ }^{\circ} \mathrm{C}$ and a mixed response at $4{ }^{\circ} \mathrm{C}$. Finally, downregulation of $i n l B$ was observed on cucumber at 4 , 10 and $30^{\circ} \mathrm{C}$. Regarding the relative transcription of $h l y$, downregulation was observed on cucumber at $4{ }^{\circ} \mathrm{C}$ and on cucumber, carrot and tomato at $10{ }^{\circ} \mathrm{C}$. On the contrary, upregulation was observed on carrot at $4{ }^{\circ} \mathrm{C}$ and on tomato and carrot at $30^{\circ} \mathrm{C}$. Finally, a mixed response was detected on tomato at $4{ }^{\circ} \mathrm{C}$ and on cucumber at $30^{\circ} \mathrm{C}$ (Figure 1). In only two cases the same transcriptomic response was observed in all four sampling times, namely downregulation of $h l y$ and $i n l B$ that were observed at $10{ }^{\circ} \mathrm{C}$ on carrot and cucumber, respectively. 



Figure 1. Cont. 


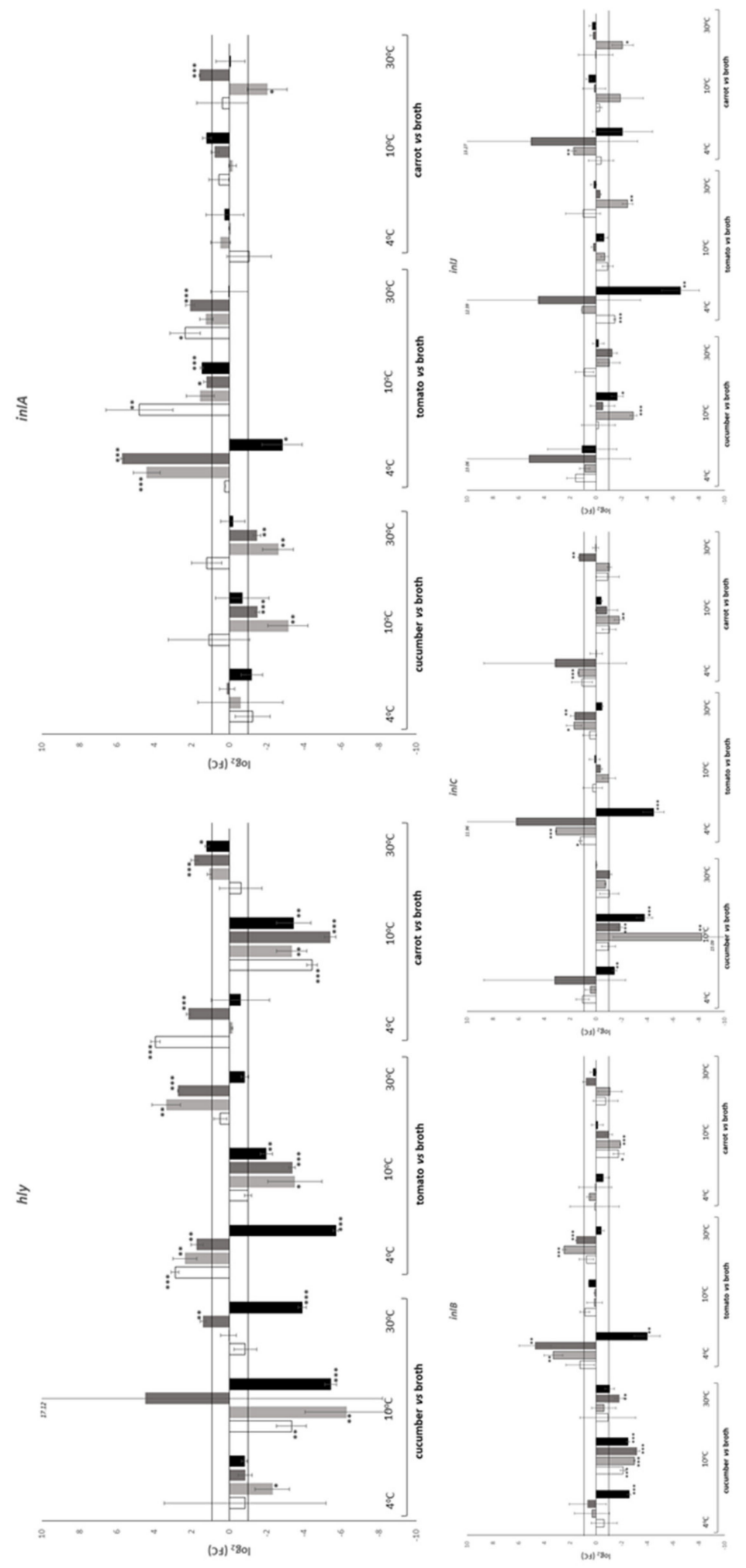

Figure 1. Effect of substrate on the relative transcription of $\operatorname{prf} A$, sigB, hly, plcA, plcB, inl $A$, inlB, inlC and inlJ during subsistence of L. monocytogenes strain LQC 15257 in BHI broth, on tomato, cucumber and carrot at 4,10 and $30^{\circ} \mathrm{C}$. BHI broth was used as control. If visible, white bars, time $0 \mathrm{~h}$; light grey bars, time $0.5 \mathrm{~h}$; dark grey bars, time $6 \mathrm{~h}$; and black bars, time $24 \mathrm{~h}$. Error bars represent the standard deviation of the mean value. Presence of asterisks indicates that the relative transcription was above 1 or below -1 (the values that were used as threshold) at $p$ value indicated by the number of asterisks $\left.{ }^{*}, p<0.05 ;{ }^{* *}, p<0.01 ;{ }^{* * *}, p<0.001\right)$. 

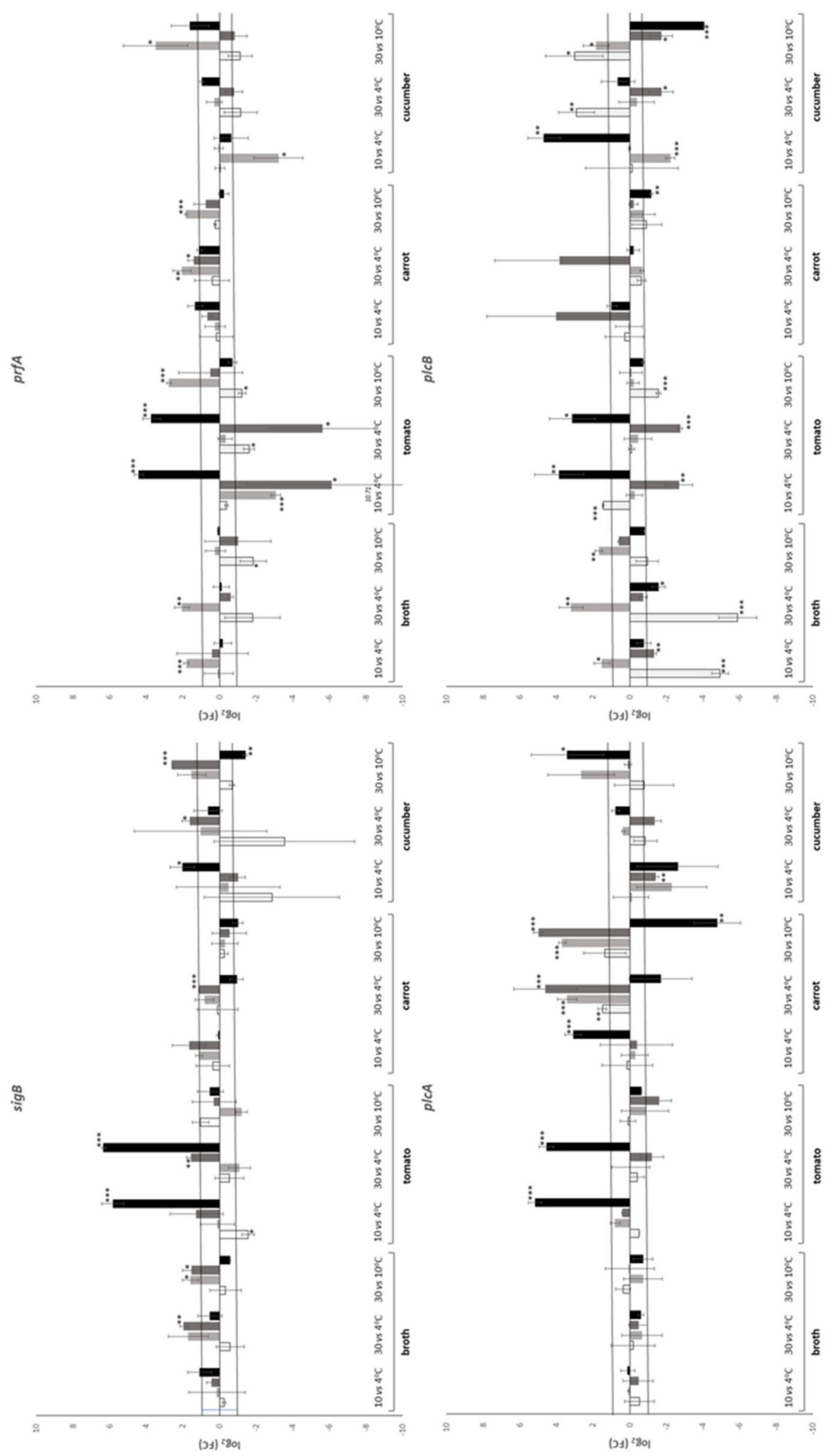

Figure 2. Cont. 

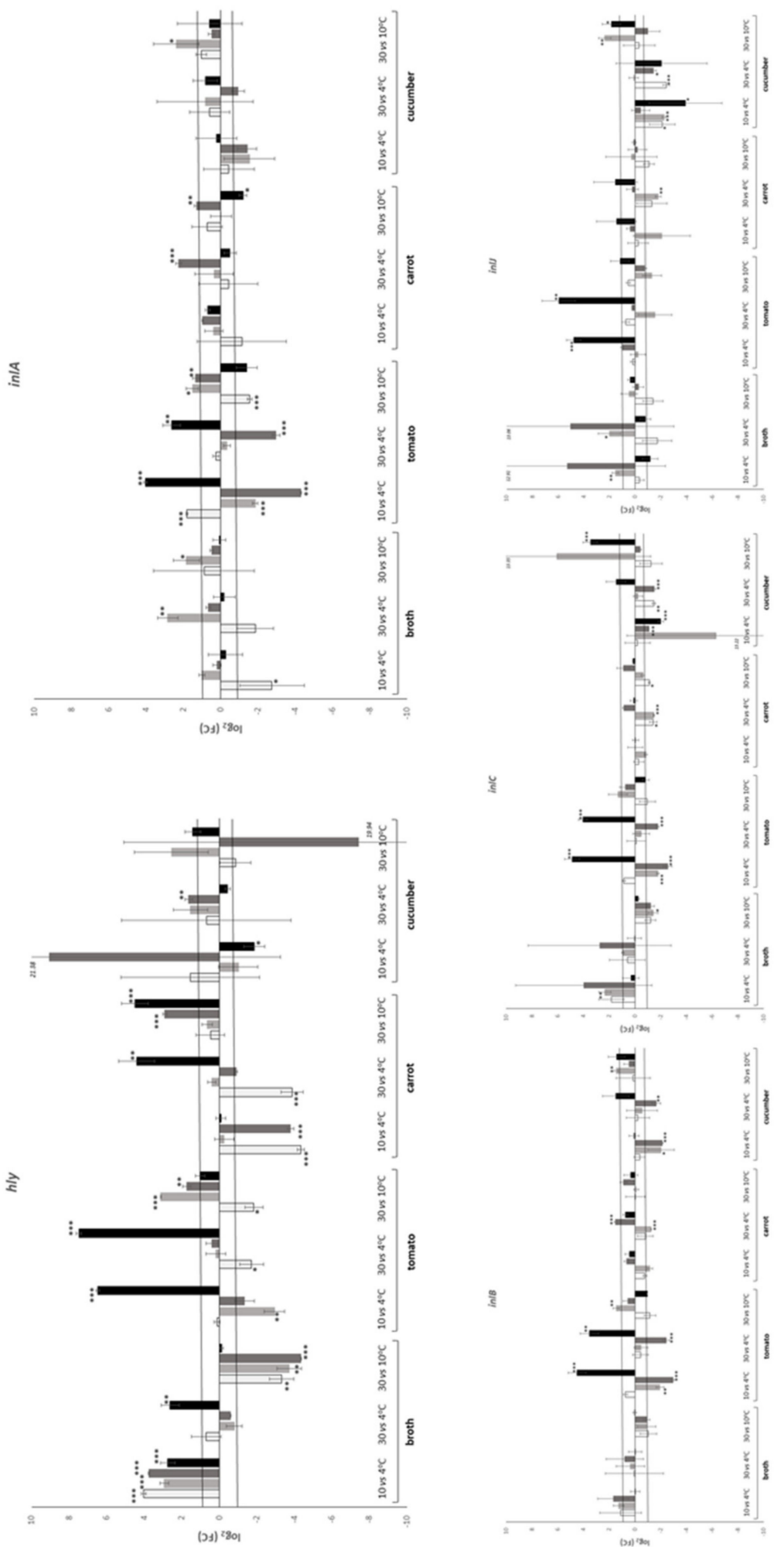

Figure 2. Effect of temperature on the relative transcription of $p r f A, \operatorname{sig} B, h l y, p l c A, p l c B$, inl $A$, inlB, inlC and inlJ during subsistence of L. monocytogenes strain LQC 15257 in BHI broth, on tomato, cucumber and carrot at 4,10 and $30^{\circ} \mathrm{C}$. The lower temperature was used as control. If visible, white bars, time $0 \mathrm{~h}$; light grey bars, time $0.5 \mathrm{~h}$; dark grey bars, time $6 \mathrm{~h}$; and black bars, time $24 \mathrm{~h}$. Error bars represent the standard deviation of the mean value. Presence of asterisks indicates that the relative transcription was above 1 or below -1 (the values that were used as threshold) at $p$ value indicated by the number of asterisks $\left({ }^{*}, p<0.05 ;{ }^{* *}, p<0.01{ }^{* * *}, p<0.001\right)$. 
Table 2. Number of samples under each experimental condition in which the relative transcription of the genes under study was below, above or within the threshold set. Percentage is given in parenthesis.

\begin{tabular}{|c|c|c|c|c|c|c|c|c|c|}
\hline \multirow[b]{2}{*}{$\log _{2}(\mathrm{FC})$} & \multicolumn{4}{|c|}{ Effect of Substrate } & \multicolumn{5}{|c|}{ Effect of Temperature } \\
\hline & total & cucumber & tomato & carrot & total & BHI broth & cucumber & tomato & carrot \\
\hline \multicolumn{10}{|l|}{$\operatorname{sig} B$} \\
\hline$<-1$ & $6(16.7)$ & $1(8.3)$ & $4(33.3)$ & $1(8.3)$ & $2(4.3)$ & $0(0.0)$ & $1(8.3)$ & $1(8.3)$ & $0(0.0)$ \\
\hline-1 to 1 & $30(83.3)$ & $11(91.7)$ & $8(66.7)$ & $11(91.7)$ & $36(74.9)$ & $9(75.0)$ & $8(66.7)$ & $8(66.7)$ & $11(91.7)$ \\
\hline$>1$ & $0(0.0)$ & $0(0.0)$ & $0(0.0)$ & $0(0.0)$ & $10(20.8)$ & $3(25.0)$ & $3(25.0)$ & $3(25.0)$ & $1(8.3)$ \\
\hline \multicolumn{10}{|l|}{$p r f A$} \\
\hline$<-1$ & $4(11.1)$ & $3(25.0)$ & $1(8.3)$ & $0(0.0)$ & $7(14.6)$ & $1(8.3)$ & $1(8.3)$ & $5(41.7)$ & $0(0.0)$ \\
\hline-1 to 1 & $29(80.6)$ & $9(75.0)$ & $8(66.7)$ & $12(100)$ & $32(66.5)$ & $9(75.0)$ & $10(83.3)$ & $4(33.3)$ & $9(75.0)$ \\
\hline$>1$ & $3(8.3)$ & $0(0.0)$ & $3(25.0)$ & $0(0.0)$ & $9(18.9)$ & $2(16.7)$ & $1(8.3)$ & $3(25.0)$ & $3(25.0)$ \\
\hline \multicolumn{10}{|l|}{$p l c A$} \\
\hline$<-1$ & $5(13.9)$ & $4(33.3)$ & $1(8.3)$ & $0(0.0)$ & $2(4.3)$ & $0(0.0)$ & $1(8.3)$ & $0(0.0)$ & $1(8.3)$ \\
\hline-1 to 1 & $27(75.0)$ & $8(66.7)$ & $11(91.7)$ & $8(66.7)$ & $37(76.8)$ & $12(100)$ & $10(83.3)$ & $10(83.3)$ & $5(41.7)$ \\
\hline$>1$ & $4(11.1)$ & $0(0.0)$ & $0(0.0)$ & $4(33.3)$ & $9(18.9)$ & $0(0.0)$ & $1(8.3)$ & $2(16.7)$ & $6(50.0)$ \\
\hline \multicolumn{10}{|l|}{$p l c B$} \\
\hline$<-1$ & $9(25.0)$ & $5(41.7)$ & $2(16.7)$ & $2(16.7)$ & $12(25.1)$ & $4(33.3)$ & $4(33.3)$ & $3(25.0)$ & $1(8.3)$ \\
\hline-1 to 1 & $20(55.6)$ & $4(33.3)$ & $7(58.3)$ & $9(75.0)$ & $26(54.1)$ & $5(41.7)$ & $4(33.3)$ & $6(50.0)$ & 11 (91.7) \\
\hline$>1$ & $7(19.4)$ & $3(25.0)$ & $3(25.0)$ & $1(8.3)$ & $10(20.8)$ & $3(25.0)$ & $4(33.3)$ & $3(25.0)$ & $0(0.0)$ \\
\hline \multicolumn{10}{|l|}{ hly } \\
\hline$<-1$ & $13(36.1)$ & $5(41.7)$ & $4(33.3)$ & $4(33.3)$ & $10(20.8)$ & $3(25.0)$ & $1(8.3)$ & $3(25.0)$ & $3(25.0)$ \\
\hline-1 to 1 & $13(36.1)$ & $6(50.0)$ & $3(25.0)$ & $4(33.3)$ & $24(50.0)$ & $4(33.3)$ & $9(75.0)$ & $5(41.7)$ & $6(50.0)$ \\
\hline$>1$ & $10(27.8)$ & $1(8.3)$ & $5(41.7)$ & $4(33.3)$ & $14(29.2)$ & $5(41.7)$ & $2(16.7)$ & $4(33.3)$ & $3(25.0)$ \\
\hline \multicolumn{10}{|l|}{ inlA } \\
\hline$<-1$ & $6(16.7)$ & $4(33.3)$ & $1(8.3)$ & $1(8.3)$ & $6(12.5)$ & $1(8.3)$ & $0(0.0)$ & $4(33.3)$ & $1(8.3)$ \\
\hline-1 to 1 & $22(61.2)$ & $8(66.7)$ & $4(33.3)$ & $10(83.3)$ & $32(66.7)$ & $9(75.0)$ & $11(91.7)$ & $3(25.0)$ & $9(75.0)$ \\
\hline$>1$ & $8(22.1)$ & $0(0.0)$ & $7(58.3)$ & $1(8.3)$ & $10(20.8)$ & $2(16.7)$ & $1(8.3)$ & $5(41.7)$ & $2(16.7)$ \\
\hline \multicolumn{10}{|l|}{ inlB } \\
\hline$<-1$ & $9(25.0)$ & $6(50.0)$ & $1(8.3)$ & $2(16.7)$ & 7 (14.6) & $0(0.0)$ & $3(25.0)$ & $3(25.0)$ & $1(8.3)$ \\
\hline-1 to 1 & $23(63.9)$ & $6(50.0)$ & $7(58.3)$ & $10(83.3)$ & $36(75.0)$ & $12(100)$ & $8(66.7)$ & $6(50.0)$ & $10(83.3)$ \\
\hline$>1$ & $4(11.1)$ & $0(0.0)$ & $4(33.3)$ & $0(0.0)$ & $5(10.4)$ & $0(0.0)$ & $1(8.3)$ & $3(25.0)$ & $1(8.3)$ \\
\hline \multicolumn{10}{|l|}{ inlC } \\
\hline$<-1$ & $6(16.7)$ & $4(33.3)$ & $1(8.3)$ & $1(8.3)$ & $10(20.8)$ & $1(8.3)$ & $3(25.0)$ & $3(25.0)$ & $3(25.0)$ \\
\hline-1 to 1 & $23(63.9)$ & $8(66.7)$ & $6(50.0)$ & $9(75.0)$ & $33(68.6)$ & $10(83.3)$ & $7(58.3)$ & $7(58.3)$ & $9(75.0)$ \\
\hline$>1$ & 7 (19.4) & $0(0.0)$ & $5(41.7)$ & $2(16.7)$ & $5(10.6)$ & $1(8.3)$ & $2(16.7)$ & $2(16.7)$ & $0(0.0)$ \\
\hline \multicolumn{10}{|l|}{ inlJ } \\
\hline$<-1$ & $5(13.9)$ & $2(16.7)$ & $2(16.7)$ & $1(8.3)$ & $6(12.5)$ & $0(0.0)$ & $5(41.7)$ & $0(0.0)$ & $1(8.3)$ \\
\hline-1 to 1 & $30(83.4)$ & $10(83.3)$ & $10(83.3)$ & $10(83.3)$ & $37(77.0)$ & $10(83.3)$ & $5(41.7)$ & $10(83.3)$ & $11(91.7)$ \\
\hline$>1$ & $1(2.7)$ & $0(0.0)$ & $0(0.0)$ & $1(8.3)$ & $6(12.5)$ & $2(16.7)$ & $2(16.7)$ & $2(16.7)$ & $0(0.0)$ \\
\hline \multicolumn{10}{|l|}{ Total } \\
\hline$<-1$ & $63(19.5)$ & $34(31.5)$ & $17(15.8)$ & $12(11.1)$ & $62(14.3)$ & $10(9.3)$ & 19 (17.6) & $22(20.4)$ & $11(10.2)$ \\
\hline-1 to 1 & $217(66.9)$ & $70(64.8)$ & 64 (59.2) & $83(76.8)$ & $293(67.7)$ & $80(74.0)$ & $72(66.7)$ & $59(54.6)$ & $81(75.0)$ \\
\hline$>1$ & 44 (13.6) & $4(3.7)$ & $27(25.0)$ & 13 (12.1) & 78 (18.0) & $18(16.7)$ & $17(15.7)$ & $27(25.0)$ & $16(14.8)$ \\
\hline
\end{tabular}

As far as the effect of temperature on the relative transcription of the genes under study was concerned, it was not significant in the majority $(67.7 \%)$ of the cases. More accurately, transcription of $\operatorname{sig} B$, inlB and inlC seemed to be unaffected by temperature. Transcription 
of $\operatorname{prf} A$, hly and inlA on tomato exhibited a mixed response, i.e., up- and down- regulation at different sampling times. The same response was observed for $p l c B$ transcription in BHI broth and on cucumber. Transcription on $p l c A$ was mostly affected on carrot; in the majority of the cases temperature increase resulted in upregulation. Transcription of hly in BHI broth and inlJ on cucumber presented a similar trend. In the first case, the relative transcription at 10 and $30^{\circ} \mathrm{C}$ compared to the one at $4{ }^{\circ} \mathrm{C}$ indicated upregulation but the relative transcription at $30^{\circ} \mathrm{C}$ compared to the one at $10{ }^{\circ} \mathrm{C}$ indicated downregulation. In the case of inlJ, the opposite was evident; the relative transcription at 10 and $30{ }^{\circ} \mathrm{C}$ compared to the one at $4{ }^{\circ} \mathrm{C}$ indicated downregulation but the relative transcription at $30{ }^{\circ} \mathrm{C}$ compared to the one at $10{ }^{\circ} \mathrm{C}$ indicated upregulation. In only one case, the same transcriptomic response was observed in all four sampling times, namely hly upregulation in BHI broth at $10^{\circ} \mathrm{C}$ compared to $4{ }^{\circ} \mathrm{C}$.

The correlation between the transcriptomic responses of the genes under study were collectively assessed by the Pearson correlation coefficient (Table 3). A total of 36 assessments were performed; no statistically significant correlation was observed in seven cases and positive correlation was observed in the remaining 29 cases.

Table 3. Pearson product moment $(\mathrm{r})$ correlations between the relative transcription of each pair of genes.

\begin{tabular}{|c|c|c|c|c|c|c|c|c|c|c|}
\hline & & $p r f A$ & sigB & $p l c A$ & $p l c B$ & hly & inlA & $i n l B$ & $i n l C$ & inlJ \\
\hline \multirow{2}{*}{$\operatorname{prfA}$} & $\mathrm{r}$ & & & & & & & & & \\
\hline & $p$ & & & & & & & & & \\
\hline \multirow[t]{2}{*}{$\operatorname{sig} B$} & $\mathrm{r}$ & 0.2548 & & & & & & & & \\
\hline & $p$ & 0.0193 & & & & & & & & \\
\hline \multirow[t]{2}{*}{$p l c A$} & $\mathrm{r}$ & 0.4970 & 0.3361 & & & & & & & \\
\hline & $p$ & 0.0000 & 0.0018 & & & & & & & \\
\hline \multirow[t]{2}{*}{$p l c B$} & $\mathrm{r}$ & 0.4347 & 0.2836 & 0.1373 & & & & & & \\
\hline & $p$ & 0.0000 & 0.0089 & 0.2128 & & & & & & \\
\hline \multirow[t]{2}{*}{ hly } & $\mathrm{r}$ & 0.4430 & 0.0654 & 0.2050 & -0.0811 & & & & & \\
\hline & $p$ & 0.0000 & 0.5545 & 0.0614 & 0.4631 & & & & & \\
\hline \multirow[t]{2}{*}{ inlA } & $\mathrm{r}$ & 0.7528 & 0.2293 & 0.3497 & 0.6363 & 0.1316 & & & & \\
\hline & $p$ & 0.0000 & 0.0359 & 0.0011 & 0.0000 & 0.2327 & & & & \\
\hline \multirow[t]{2}{*}{$i n l B$} & $\mathrm{r}$ & 0.7959 & 0.2581 & 0.4265 & 0.3001 & 0.4618 & 0.7264 & & & \\
\hline & $p$ & 0.0000 & 0.0178 & 0.0001 & 0.0056 & 0.0000 & 0.0000 & & & \\
\hline \multirow[t]{2}{*}{ inlC } & $\mathrm{r}$ & 0.7218 & 0.2803 & 0.4250 & 0.1368 & 0.5274 & 0.5850 & 0.8322 & & \\
\hline & $p$ & 0.0000 & 0.0098 & 0.0001 & 0.2147 & 0.0000 & 0.0000 & 0.0000 & & \\
\hline \multirow[t]{2}{*}{ inlJ } & $r$ & 0.4045 & 0.4817 & 0.3182 & 0.1934 & 0.3311 & 0.3646 & 0.5134 & 0.6898 & \\
\hline & $p$ & 0.0001 & 0.0000 & 0.0032 & 0.0780 & 0.0021 & 0.0006 & 0.0000 & 0.0000 & \\
\hline
\end{tabular}

Statistically significant correlations $(p<0.05)$ are presented in bold.

Weak correlation $(0.00<\mathrm{r}<0.29)$ was indicated in 5 cases, moderate correlation $(0.30<\mathrm{r}<0.49)$ was indicated in 14 cases and strong correlation $(0.50<\mathrm{r}<0.99)$ in 10 cases. The strongest correlation $(\mathrm{r}>0.70)$ was indicated between prfA and inlA, inlB, inlC, between inlA and inlB, as well as between inlB and inlC.

\section{Discussion}

The pathogenic potential of $L$. monocytogenes, assessed almost exclusively by invasion to cell lines, such as Caco-2, THP-1 and HT-29, is affected by abiotic and biotic stimuli that include exposure to temperature, acid and osmotic fluctuations as well as the food 
matrix and co-existing microorganisms [18-32]. Correlation between the transcriptomic response of the pathogen to the above stresses with invasiveness, in some cases was successful $[13,21]$. Several studies have assessed the transcription of virulence associated genes during growth of L. monocytogenes on a food matrix at various storage temperatures and times [8-13,15-17]. The basic conclusions of these studies were that their transcription was, in the majority of the cases, affected by the experimental conditions (time, temperature, food matrix) and this effect was strain dependent. Indeed, when more than one strain was included in a study, substantial differences in gene transcription were reported $[8,10-13,15]$. In the present study, only L. monocytogenes strain LQC 15257 was employed. The relative transcription of virulence associated genes of this strain was also assessed on the surface of rocket and melon [16], on the surface of BHI agar under the effect of lemongrass essential oil [47], in co-culture with Aspergillus flavus strain 18.4 [48] as well as after in vitro exposure to human gastric and duodenal aspirates [45]. Thus, a database of responses to various stimuli has been established, which is enriched with the transcriptomic responses assessed in the present study.

sig $B$ and prfA possess very important role in homeostasis and virulence capacity of the pathogen [1]. Moreover, transcription of $\operatorname{prfA}$ may be initiated by three promoter sites, one of which is partially $\sigma^{\mathrm{B}}$-dependent [48]. In the present study, only weak association of the relative transcription between $\operatorname{sig} B$ and $\operatorname{prf} A$ was revealed. In addition, relative transcription of both genes seemed to be unaffected by substrate and temperature, with a few notable exceptions. Among them, downregulation of $\operatorname{sig} B$ was observed on tomato at all temperatures. However, this was accompanied by up- and down- regulation of $p r f A$ at 4 ${ }^{\circ} \mathrm{C}$ (at different sampling times) and upregulation at $30^{\circ} \mathrm{C}$. Downregulation of $p r f A$ could be explained through the effect of the $\sigma^{\mathrm{B}}$-dependent promoter $\mathrm{P} 2_{\text {prf }}$, while upregulation through the effect of the $\sigma^{\mathrm{B}}$-independent promoter $\mathrm{P} 1_{p r f A}$. The bicistronic plcA-prfA mRNA, which is initiated by the $p l c A$ promoter, should be absent at temperatures below $37^{\circ} \mathrm{C}$ [49], i.e., the temperatures employed in the present study. This seems to be partially verified, considering the only moderate correlation between $\operatorname{prf} A$ and $p l c A$, which was indicated by Pearson correlation coefficient.

Internalins InlA, InlB, InlC and InlJ are necessary for effective invasion. Indeed, deletion mutants exhibited significantly attenuated virulence capacity [5,50-52]. In the present study, based on the times that $\log _{2}(\mathrm{FC})$ value indicated lack of regulation, the relative transcription of $i n l A, i n l B, i n l C$ and inlJ was generally not affected by substrate and temperature. However, in several cases, effect of substrate and temperature on internalin genes relative transcription was observed. The substrate mostly affected inlA, inlB and inlC relative transcription and only marginally the one of inlJ. Subsistence on tomato affected inlA and inlC relative transcription more than subsistence on cucumber did. On the contrary, cucumber affected inlB relative transcription more than tomato did. In nearly all cases, subsistence on cucumber resulted in downregulation, while subsistence on tomato in upregulation; carrot had only marginal effect. Regarding the effect of temperature, this was more pronounced on tomato and cucumber and the genes mostly affected were inlA, $i n l B$ and $i n l C$ in the first case, and inlC and inlJ in the second. All the above suggest that transcription regulation of $i n l A, i n l B$ and $i n l C$ is related. Indeed, inl $A$ and inlB form the operon inlAB, the transcription of which is controlled by both $\sigma^{\mathrm{B}}$ and PrfA; transcription of inlC is controlled by PrfA, while transcription of inlJ by none of the above [53]. The effect of $\operatorname{prf} A$ on the relative transcription of $i n l A$, inlB and $i n l C$ was also verified by the high (above 0.7 ) Pearson correlation coefficient. On the contrary, only a moderate correlation was exhibited between $\operatorname{prf} A$ and inlJ as well as between $\operatorname{sig} B$ and all four internalins.

The role of $h l y$ in virulence has been adequately highlighted; it encodes for (LLO), the absence of which has been reported to result in avirulence [54,55]. However, Phelps et al. [52] reported that LLO-dependent internalization did not occur in the case of cytotrophoblasts and endothelial cells, which indicates that LLO deficient strains avirulence is tissue dependent. Relative transcription of $h l y$ seemed to be substantially affected by substrate and temperature. More accurately, subsistence on tomato seemed to affect more 
than carrot, which in turns affected more than cucumber. This effect was mostly observed at 4 and $10{ }^{\circ} \mathrm{C}$. In the latter temperature, hly was downregulated in all cases, while in the former, hly was upregulated in the majority of the cases. Transcription of hly may be initiated by three promoter sites, two of which are PrfA-dependent since they contain a PrfA box [56]. In the present study, activation of the third promoter site is indicated, taking into consideration the moderate correlation between $\operatorname{prfA}$ and $h l y$ transcription revealed by Pearson correlation coefficient.

plcB also holds a very important role in pathogenesis [57]. Subsistence of the pathogen on cucumber affected $p l c B$ relative transcription more than tomato and carrot did. In the majority of the cases, a mixed response, i.e., up- and down-regulation at different sampling times, was observed. Regarding the effect of temperature, this was more pronounced on cucumber, followed by BHI broth and tomato. The effect of temperature on carrot was only marginal. As in the previous case, a mixed response was evident. Transcription of $p l c B$ is PrfA-dependent [58]. However, the data obtained in the present study revealed only a moderate correlation between $\operatorname{prf} A$ and $p l c B$ transcription.

\section{Conclusions}

Subsistence of the pathogen on carrot surface had only marginal effect on the relative transcription of the virulence associated genes assessed in the present study. On the contrary, the relative transcription of $\operatorname{sig} B, \operatorname{prf} A, h l y$, inlA and inlC was more affected on tomato surface, while the relative transcription of $p l c A, p l c B$ and $i n l B$ was more affected on cucumber surface. In the majority of the cases, this effect was dependent on the storage temperature employed. These results constitute a significant input to the ongoing effort to elucidate the physiology of the pathogen during subsistence in food matrices, which may concomitantly enable targeted virulence-attenuation approaches.

Author Contributions: Conceptualization, S.P. and E.H.D.; methodology, S.P. and C.K.; data curation, S.P. and C.K.; writing-original draft preparation, S.P.; writing-review and editing, S.P., C.K. and E.H.D.; funding acquisition, S.P. and E.H.D. All authors have read and agreed to the published version of the manuscript.

Funding: This research was funded by the European Union's Seventh Framework Programme for research, technological development and demonstration under grant agreement no 289719 (Project QUAFETY).

Institutional Review Board Statement: Not applicable.

Informed Consent Statement: Not applicable.

Data Availability Statement: The data presented in this study are available in the manuscript.

Conflicts of Interest: The authors declare no conflict of interest.

\section{References}

1. Radoshevich, L.; Cossart, P. Listeria monocytogenes: Towards a complete picture of its physiology and pathogenesis. Nat. Rev. Microbiol. 2018, 16, 32-46. [CrossRef]

2. Vadia, S.; Arnett, E.; Haghighat, A.C.; Wilson-Kubalek, E.M.; Tweten, R.K.; Seveau, S. The pore-forming toxin listeriolysin O mediates a novel entry pathway of L. monocytogenes into human hepatocytes. PLoS Pathog. 2011, 7, e1002356. [CrossRef]

3. Alberti-Segui, C.; Goeden, K.R.; Higgins, D.E. Differential function of Listeria monocytogenes listeriolysin O and phospholipases C in vacuolar dissolution following cell-to-cell spread. Cell. Microbiol. 2007, 9, 179-195. [CrossRef] [PubMed]

4. Rajabian, T.; Gavicherla, B.; Heisig, M.; Mueller-Altrock, S.; Goebel, W.; Gray-Owen, S.D.; Ireton, K. The bacterial virulence factor InlC perturbs apical cell junctions and promotes cell-to-cell spread of Listeria. Nat. Cell Biol. 2009, 11, 1212-1218. [CrossRef] [PubMed]

5. Sabet, C.; Lecuit, M.; Cabanes, D.; Cossart, P.; Bierne, H. LPXTG protein InlJ, a newly identified internalin involved in Listeria monocytogenes virulence. Infect. Immun. 2005, 73, 6912-6922. [CrossRef]

6. Gaballa, A.; Guariglia-Oropeza, V.; Wiedmann, M.; Boor, K.J. Cross talk between SigB and PrfA in Listeria monocytogenes facilitates transitions between extra- and intracellular environments. Microbiol. Mol. Biol. Rev. 2019, 83, e00034-19. [CrossRef] 
7. Henderson, L.O.; Gaballa, A.; Orsi, R.H.; Boor, K.J.; Wiedmann, M.; Guariglia-Oropeza, V. Transcriptional profiling of the L. monocytogenes PrfA regulon identifies six novel putative PrfA-regulated genes. FEMS Microbiol. Lett. 2020, 367 , fnaa193. [CrossRef] [PubMed]

8. Olesen, I.; Thorsen, L.; Jespersen, L. Relative transcription of Listeria monocytogenes virulence genes in liver pates with varying $\mathrm{NaCl}$ content. Int. J. Food Microbiol. 2010, 141, S60-S68. [CrossRef] [PubMed]

9. Bae, D.; Crowley, M.R.; Wang, C. Transcriptome analysis of Listeria monocytogenes grown on a ready-to-eat meat matrix. J. Food Prot. 2011, 74, 1104-1111. [CrossRef]

10. Rantsiou, K.; Greppi, A.; Garosi, M.; Acquadro, A.; Mataragas, M.; Cocolin, L. Strain dependent expression of stress response and virulence genes of Listeria monocytogenes in meat juices as determined by microarray. Int. J. Food Microbiol. 2012, 152, 116-122 [CrossRef]

11. Rantsiou, K.; Mataragas, M.; Alessandria, V.; Cocolin, L. Expression of virulence genes of Listeria monocytogenes in food. J. Food Saf. 2012, 32, 161-168. [CrossRef]

12. Mataragas, M.; Rovetto, F.; Bellio, A.; Alessandria, V.; Rantsiou, K.; Decastelli, L.; Cocolin, L. Differential gene expression profiling of Listeria monocytogenes in Cacciatore and Felino salami to reveal potential stress resistance biomarkers. Food Microbiol. 2015, 46, 408-417. [CrossRef] [PubMed]

13. Duodu, S.; Holst-Jensen, A.; Skjerdal, T.; Cappelier, J.M.; Pilet, M.F.; Loncarevic, S. Influence of storage temperature on gene expression and virulence potential of Listeria monocytogenes strains grown in a salmon matrix. Food Microbiol. 2010, 27, 795-801. [CrossRef] [PubMed]

14. Pilevar, Z.; Hosseini, H.; Abdollahzadeh, E.; Shojaee-Aliabadi, S.; Tajedin, E.; Yousefi, M.; Bahrami, A.; Khosroshahi, N.K. Effect of Zataria multiflora Boiss. essential oil, time, and temperature on the expression of Listeria monocytogenes virulence genes in broth and minced rainbow trout. Food Control 2020, 109, 106863. [CrossRef]

15. Alessandria, V.; Rantsiou, K.; Dolci, P.; Zeppa, G.; Cocolin, L.A. Comparison of gene expression of Listeria monocytogenes in vitro and in the soft cheese Crescenza. Int. J. Dairy Technol. 2013, 66, 83-89. [CrossRef]

16. Hadjilouka, A.; Molfeta, C.; Panagiotopoulou, O.; Paramithiotis, S.; Mataragas, M.; Drosinos, E.H. Expression of Listeria monocytogenes key virulence genes during growth in liquid medium, on rocket and melon at 4,10 and $30{ }^{\circ} \mathrm{C}$. Food Microbiol. 2016, 55, 7-15. [CrossRef]

17. Kang, J.; Burall, L.; Mammel, M.K.; Datta, A.R. Global transcriptomic response of Listeria monocytogenes during growth on cantaloupe slices. Food Microbiol. 2019, 77, 192-201. [CrossRef] [PubMed]

18. Conte, M.P.; Petrone, G.; Di Biase, A.; Ammendolia, M.G.; Superti, F.; Seganti, L. Acid tolerance in Listeria monocytogenes influences invasiveness of enterocyte-like cells and macrophagelike cells. Microb. Pathog. 2000, 29, 137-144. [CrossRef]

19. Conte, M.P.; Petrone, G.; Di Biase, A.M.; Longhi, C.; Penta, M.; Tinari, A.; Superti, F.; Fabozzi, G.; Visca, P.; Seganti, L. Effect of acid adaptation on the fate of Listeria monocytogenes in THP-1 human macrophages activated by gamma interferon. Infect. Immun. 2002, 70, 4369-4378. [CrossRef] [PubMed]

20. Garner, M.R.; James, K.E.; Callahan, M.C.; Wiedmann, M.; Boor, K.J. Exposure to salt and organic acids increases the ability of Listeria monocytogenes to invade Caco-2 cells but decreases its ability to survive gastric stress. Appl. Environ. Microbiol. 2006, 72, 5384-5395. [CrossRef] [PubMed]

21. Zilelidou, E.A.; Milina, V.; Paramithiotis, S.; Zoumpopoulou, G.; Poimenidou, S.V.; Mavrogonatou, E.; Kletsas, D.; Papadimitriou, K.; Tsakalidou, E.; Skandamis, P.N. Differential modulation of Listeria monocytogenes fitness, in vitro virulence and transcription of virulence-associated genes in response to the presence of different microorganisms. Appl. Environ. Microbiol. 2020, 86, e01165-20. [CrossRef] [PubMed]

22. Werbrouck, H.; Vermeulen, A.; Van Coillie, E.; Messens, W.; Herman, L.; Devlieghere, F.; Uyttendaele, M. Influence of acid stress on survival, expression of virulence genes and invasion capacity into Caco-2 cells of Listeria monocytogenes strains of different origins. Int. J. Food Microbiol. 2009, 134, 140-146. [CrossRef]

23. Rieu, A.; Guzzo, J.; Piveteau, P. Sensitivity to acetic acid, ability to colonize abiotic surfaces and virulence potential of Listeria monocytogenes EGD-e after incubation on parsley leaves. J. Appl. Microbiol. 2010, 108, 560-570. [CrossRef]

24. Wałecka, E.; Molenda, J.; Karpíšková, R.; Bania, J. Effect of osmotic stress and culture density on invasiveness of Listeria monocytogenes strains. Int. J. Food Microbiol. 2011, 144, 440-445. [CrossRef]

25. Pricope-Ciolacu, L.; Nicolau, A.I.; Wagner, M.; Rychli, K. The effect of milk components and storage conditions on the virulence of Listeria monocytogenes as determined by a Caco-2 cell assay. Int. J. Food Microbiol. 2013, 166, 59-64. [CrossRef]

26. Colas-Meda, P.; Vinas, I.; Oliveira, M.; Anguera, M.; Serrano, J.C.E.; Abadias, M. Exposure to minimally processed pear and melon during shelf life could modify the pathogenic potential of Listeria monocytogenes. Food Microbiol. 2017, 62, 275-281. [CrossRef]

27. Wałecka-Zacharska, E.; Korkus, J.; Skowron, K.; Wietlicka-Piszcz, M.; Kosek-Paszkowska, K.; Bania, J. Effect of temperatures used in food storage on duration of heat stress induced invasiveness of L. monocytogenes. Microorganisms 2019, 7, 467. [CrossRef]

28. Alves, A.; Magalhães, R.; Brandão, T.R.S.; Pimentel, L.; Rodríguez-Alcalá, L.M.; Teixeira, P.; Ferreira, V. 2020. Impact of exposure to cold and cold-osmotic stresses on virulence-associated characteristics of Listeria monocytogenes strains. Food Microbiol. 2020, 87, 103351. [CrossRef]

29. Tan, Q.; Xu, H.; Chen, T.; Li, P.; Aguilar, Z.P.; Xu, D.; Ming, X.; Xu, F.; Wei, H. Differential expression of virulence and stress fitness genes during interaction between Listeria monocytogenes and Bifidobacterium longum. Biosci. Biotechnol. Biochem. 2012, 76, 699-704. [CrossRef] [PubMed] 
30. Dutra, V.; Silva, A.C.; Cabrita, P.; Peres, C.; Malcata, X.; Brito, L. Lactobacillus plantarum LB95 impairs the virulence potential of Gram-positive and Gram-negative food-borne pathogens in HT-29 and Vero cell cultures. J. Med. Microbiol. 2016, 65, 28-35. [CrossRef] [PubMed]

31. Collazo, C.; Abadías, M.; Colás-Medà, P.; Iglesias, M.B.; Granado-Serrano, A.B.; Serrano, J.; Viñas, I. Effect of Pseudomonas graminis strain CPA-7 on the ability of Listeria monocytogenes and Salmonella enterica subsp. enterica to colonize Caco-2 cells after pre-incubation on fresh-cut pear. Int. J. Food Microbiol. 2017, 262, 55-62. [CrossRef] [PubMed]

32. Iglesias, M.B.; Viñas, I.; Colás-Medà, P.; Collazo, C.; Serrano, J.C.; Abadias, M. Adhesion and invasion of Listeria monocytogenes and interaction with Lactobacillus rhamnosus GG after habituation on fresh-cut pear. J. Funct. Foods 2017, 34, 453-460. [CrossRef]

33. Heisick, J.E.; Wagner, D.E.; Niermand, M.L.; Peeler, J.T. Listeria spp. found on fresh market produce. Appl. Environ. Microbiol. 1989, 55, 1925-1927. [CrossRef]

34. Vahidy, R. Isolation of Listeria monocytogenes from fresh fruits and vegetables. HortScience 1992, 27, 62. [CrossRef]

35. Hadjilouka, A.; Mantzourani, K.S.; Katsarou, A.; Cavaiuolo, M.; Ferrante, A.; Paramithiotis, S.; Mataragas, M.; Drosinos, E.H. Estimation of Listeria monocytogenes and Escherichia coli O157:H7 prevalence and levels in naturally contaminated rocket and cucumber samples by deterministic and stochastic approaches. J. Food Prot. 2015, 78, 311-322. [CrossRef] [PubMed]

36. Arumugaswamy, R.K.; Ali, G.R.; Abd Hamid, S.N. Prevalence of Listeria monocytogenes in foods in Malaysia. Int. J. Food Microbiol. 1994, 23, 117-121. [CrossRef]

37. Ponniah, J.; Robin, T.; Paie, M.S.; Radu, S.; Ghazali, F.M.; Kqueen, C.Y.; Nishibuchi, M.; Nakaguchi, Y.; Malakar, P.K. Listeria monocytogenes in raw salad vegetables sold at retail level in Malaysia. Food Control 2010, 21, 774-778. [CrossRef]

38. Ajayeoba, T.A.; Atanda, O.O.; Obadina, A.O.; Bankole, M.O.; Adelowo, O.O. The incidence and distribution of Listeria monocytogenes in ready-to-eat vegetables in South-Western Nigeria. Food Sci. Nutr. 2016, 4, 59-66. [CrossRef]

39. Farber, J.M.; Sanders, G.W.; Johnston, M.A. A survey of various foods for the presence of Listeria species. J. Food Prot. 1989, 52, 456-458. [CrossRef]

40. Park, W.J.; Ryu, H.Y.; Lim, G.Y.; Lee, Y.D.; Park, J.H. Microbial prevalence and quality of organic farm produce from various production sites. Korean J. Food Sci. Technol. 2014, 46, 262-267. [CrossRef]

41. Roth, L.; Simonne, A.; House, L.; Ahn, S. Microbiological analysis of fresh produce sold at Florida farmers' markets. Food Control 2018, 92, 444-449. [CrossRef]

42. Odumeru, J.A.; Mitchell, S.J.; Alves, D.M.; Lynch, J.A.; Yee, A.J.; Wang, S.L.; Styliadis, S.; Farber, J.M. Assessment of the microbiological quality of ready-to-use vegetables for health-care food services. J. Food Prot. 1997, 60, 954-960. [CrossRef]

43. Ho, J.L.; Shands, K.N.; Friedland, G.; Eckind, P.; Fraser, D.W. An outbreak of type 4b Listeria monocytogenes infection involving patients from eight Boston hospitals. Arch. Intern. Med. 1986, 146, 520-524. [CrossRef]

44. Hadjilouka, A.; Andritsos, N.D.; Paramithiotis, S.; Mataragas, M.; Drosinos, E.H. Listeria monocytogenes serotype prevalence and biodiversity in diverse food products. J. Food Prot. 2014, 77, 2115-2120. [CrossRef]

45. Hadjilouka, A.; Gkolfakis, P.; Patlaka, A.; Grounta, A.; Vourli, G.; Paramithiotis, S.; Touloumi, G.; Triantafyllou, K.; Drosinos, E.H. In vitro transcription of Listeria monocytogenes after exposure to human gastric and duodenal aspirates. J. Food Prot. 2020, 83, 89-100. [CrossRef] [PubMed]

46. Andersen, C.L.; Jensen, J.L.; Ørntoft, T.F. Normalization of real-time quantitative reverse transcription-PCR data: A model-based variance estimation approach to identify genes suited for normalization, applied to bladder and colon cancer data sets. Cancer Res. 2004, 64, 5245-5250. [CrossRef] [PubMed]

47. Hadjilouka, A.; Mavrogiannis, G.; Mallouchos, A.; Paramithiotis, S.; Mataragas, M.; Drosinos, E.H. Effect of lemongrass essential oil on Listeria monocytogenes gene expression. LWT-Food Sci. Technol. 2017, 77, 510-516. [CrossRef]

48. Lappa, I.; Dionysopoulou, A.M.; Paramithiotis, S.; Georgiadou, M.; Drosinos, E.H. Dual transcriptional profile of Aspergillus flavus during co-culture with Listeria monocytogenes and AFB1 production: A pathogen: Pathogen interaction. Pathogens 2019, 8, 198. [CrossRef]

49. Leimeister-Waechter, M.; Domann, E.; Chakraborty, T. The expression of virulence genes in Listeria monocytogenes is thermoregulated. J. Bacteriol. 1992, 174, 947-952. [CrossRef]

50. Dramsi, S.; Biswas, I.; Maguin, E.; Braun, L.; Mastroeni, P.; Cossart, P. Entry of Listeria monocytogenes into hepatocytes requires expression of InIB, a surface protein of the internalin multigene family. Mol. Microbiol. 1995, 16, 251-261. [CrossRef]

51. Engelbrecht, F.; Chun, S.K.; Ochs, C.; Hess, J.; Lottspeich, F.; Goebel, W.; Sokolovic, Z. A new PrfA-regulated gene of Listeria monocytogenes encoding a small, secreted protein which belongs to the family of internalins. Mol. Microbiol. 1996, $21,823-837$. [CrossRef]

52. Phelps, C.C.; Vadia, S.; Arnett, E.; Tan, Y.; Zhang, X.; Pathak-Sharma, S.; Gavrilin, M.A.; Seveau, S. Relative roles of listeriolysin O, InlA and InlB in Listeria monocytogenes uptake by host cells. Infect. Immun. 2018, 86, e00555-18. [CrossRef] [PubMed]

53. De las Heras, A.; Cain, R.J.; Bielecka, M.K.; Vázquez-Boland, J.A. Regulation of Listeria virulence: PrfA master and commander. Curr. Opin. Microbiol. 2011, 14, 118-127. [CrossRef]

54. Kathariou, S.; Metz, P.; Hof, H.; Goebel, W. Tn916-induced mutations in the hemolysin determinant affecting virulence of Listeria monocytogenes. J. Bacteriol. 1987, 169, 1291-1297. [CrossRef] [PubMed]

55. Cossart, P.; Vicente, M.F.; Mengaud, J.; Baquero, F.; Perez-Diaz, J.C.; Berche, P. Listeriolysin O is essential for virulence of Listeria monocytogenes: Direct evidence obtained by gene complementation. Infect. Immun. 1989, 57, 3629-3636. [CrossRef] [PubMed] 
56. Domann, E.; Wehland, J.; Niebuhr, K.; Haffner, C.; Leimeister-Wachter, M.; Chakraborty, T. Detection of PrfA-independent promoter responsible for listeriolysin gene expression in mutant Listeria monocytogenes strains lacking the PrfA regulator. Infect. Immun. 1993, 61, 3073-3075. [CrossRef]

57. Grundling, A.; Gonzalez, M.D.; Higgins, D.E. Requirement of the Listeria monocytogenes broad-range phospholipase PC-PLC during infection of human epithelial cells. J. Bacteriol. 2003, 185, 6295-6307. [CrossRef] [PubMed]

58. Dussurget, O. New insights into determinants of Listeria monocytogenes virulence. Int. Rev. Cell Mol. Biol. 2008, $270,1-38$. 